\title{
Pengaruh Self-Regulated Learning, Self-Efficacy dan Perhatian Orangtua Terhadap Prestasi Belajar Matematika Siswa
}

\author{
Sugiyana \\ Guru Bimbingan dan Konseling \\ SMP Negeri 1 Purwosari Gunungkidul \\ Giripurwo, Purwosari, Gunungkidul, D.I Yogyakarta, Indonesia \\ Email: sugiyana.gk@gmail.com
}

\begin{abstract}
This research aims at revealing the effect of self regulated learning, self-efficacy and parental attention towards math learning achievement of the $8^{\text {th }}$ grade students. It took place in SMP Negeri 1 Purwosari Gunungkidul where there were 89 students of $8^{\text {th }}$ grade participating as research subjects. The method used to collect the data was self regulated learning scale, self-efficacy scale and parental attention scale. The students' math learning achievement data was obtained from raport documentation on odd semester while the other data was collected from even semester. Multiple regression analysis was used as data analysis technique. The regression analysis indicated significant difference between self regulated learning and math learning achievement with value of $0.516(0.516>0.05)$. The self-efficacy towards math learning achievement was $0.611(0.611>0.05)$. Parental attention towards the math learning achievement was 0.193 $(0.193>0.05)$. Based on the data analysis result, it showed that there was no meaningful effect from those three variables to math learning achievement. The variant analysis significance was $0.494(0.494>0.05)$. Self-regulated learning, self efficacy and parental attention together gave no impact to math learning achievement which means that it was under the influence of the untested unknown. This research can be used by the guidance and counceling teachers as a consideration for improving the students learning achievement through learning guidance service as well as by math teachers to improve their math learning achievement.
\end{abstract}

Keywords: self-regulated learning, self-efficacy, parental attention, math learning achievement

Tujuan penelitian ini untuk mengetahui pengaruh self regulated learning, self-efficacy, dan perhatian orangtua terhadap prestasi belajar matematika pada siswa kelas VIII. Penelitian ini mengambil lokasi di SMP Negeri 1 Purwosari Gunungkidul. Jumlah subjek 89 siswa kelas VIII. Metode pengumpulan data menggunakan skala self regulated learning, skala self-efficacy, dan skala perhatian orangtua. Data prestasi belajar matematika diperoleh dari dokumen rapor pada semester ganjil sedangkan pengambilan data pada semester genap. Teknik analisis data yang digunakan adalah analisis regresi ganda. Hasil analisis regresi menunjukkan hasil signifikansi antara self regulated learning terhadap prestasi belajar matematika sebesar 0,516 (516 > 0,05). Self-efficacy terhadap prestasi belajar matematika sebesar 0,611 $(0,611>$ $0,05)$. Perhatian orangtua terhadap prestasi belajar matematika sebesar $0,193(0,193>0,05)$. Hasil analisis data menunjukkan tidak ada pengaruh dari ketiga variabel tersebut terhadap prestasi belajar matematika. Signifikansi analisis varian sebesar 0,494 (0,494>0,05), self regulated learning, self-efficacy, dan perhatian orangtua secara bersama-sama tidak berpengaruh terhadap prestasi belajar matematika, berarti dipengaruhi oleh faktor lain yang tidak diteliti. Penelitian ini dapat dijadikan pertimbangan guru bimbingan dan konseling dalam upaya meningkatkan prestasi belajar siswa melalui layanan bimbingan belajar, dan bagi guru bidang studi matematika dapat dijadikan sebagai pertimbangan dalam peningkatan prestasi belajar matematika siswa.

Kata kunci: self-regulated learning, self-efficacy, perhatian orangtua, dan prestasi belajar matematika

\section{Pendahuluan}

Prestasi belajar Matematika yang telah dicapai peserta didik dapat diketahui dengan diadakan kegiatan evaluasi pembelajaran. Evaluasi pembelajaran merupakan kegiatan yang dilakukan secara sistematis dengan mengumpulkan buktibukti untuk menentukan keberhasilan belajar. Hamalik (2001) menyatakan tentang evaluasi prestasi belajar merupakan keseluruhan kegiatan pengukuran (pengumpulan data dan informasi), pengolahan, penafsiran, dan pertimbangan untuk 
membuat keputusan tentang tingkat prestasi belajar yang dicapai oleh siswa setelah melakukan kegiatan dalam upaya mencapai tujuan pembelajaran yang telah ditetapkan.

Fakta yang ada berdasarkan dokumen daftar nilai guru matematika siswa kelas VIII di SMPN 1 Purwosari Gunungkidul tahun pelajaran 2014/2015, diperoleh data bahwa 65,17 \% siswa menunjukkan prestasi belajar Matematika yang rendah (dibawah $\mathrm{KKM}$ ), dengan nilai rata-rata 74,10 (KKM 75). Menurut keterangan dari beberapa siswa, pelajaran matematika merupakan pelajaran yang sulit untuk dipahami, hal ini sering dikeluhkan oleh siswa kepada guru Bimbingan Konseling, dan juga dibuktikan dengan nilai rapot siswa yang menunjukkan bahwa nilai matematika memang tergolong rendah. Keterangan yang diperoleh dari guru pengampu mata pelajaran matematika siswa kurang mempunyai semangat untuk mengikuti pembelajaran matematika, hal ini dibuktikan dengan hasil nilai ulangan harian yang kurang adanya peningkatan kearah yang lebih baik dan hasil nilai rapot yang juga kurang memuaskan, lebih lanjut menurut guru matematika, banyak siswa yang tidak semangat untuk belajar matematika, hal ini karena kurangnya kesadaran siswa akan pentingnya belajar dan apa yang harus dilakukan saat belajar, tidak mau berusaha untuk belajar lebih keras, tidak mempunyai kreatifitas, kurang percaya diri dan kurang mempunyai sikap optimis.

Prestasi belajar matematika siswa cukup rendah, dari hasil wawancara yang dilakasanakan pada tanggal 8 September 2014 dengan beberapa siswa di SMPN 1 Purwosari Gunungkidul karena sebagian siswa belum memiliki keyakinan bahwa apa yang dilakukan dalam kegiatan belajar adalah untuk dirinya di masa depan. Sejalan dengan hal tersebut, maka dalam proses belajar siswa di sekolah masih menunjukkan sikap apriori (masa bodoh), merasa malas, dan beberapa siswa yang merasa mengalami kesulitan dalam belajar matematika. Siswa beranggapan bahwa matematika adalah pelajaran yang sulit dan memerlukan suatu pemikiran yang keras dan otak yang cerdas. Anggapan ini menyebabkan mereka patah semangat dalam belajar. Mereka enggan mencoba dan lebih suka mengatakan tidak bisa sebelum mencoba mengerjakan soal yang diberikan guru sehingga cenderung pasif. Hal ini telah menjadi isu bahwa penguasaan siswa terhadap matematika (khusus matematika sekolah) adalah rendah bila dibandingkan dengan mata pelajaran lain. Kondisi inilah yang terjadi di SMPN 1 Purwosari Gunungkidul, bahwa prestasi belajar siswa khususnya prestasi belajar matematika tergolong cukup rendah.

Penelitian ini akan menguji apakah terdapat pengaruh yang signifikan baik secara bersamasama maupun sendiri-sendiri antara self regulated learning, self-efficacy dan perhatian orangtua terhadap prestasi belajar matematika. Prestasi belajar matematika yang rendah menjadi fokus permasalahan yang harus segera ditemukan faktor penyebabnya, agar berbagai altrenatif solusi dapat dtemukan pula oleh para peneliti, pendidik, dan stake holder untuk mengatasi permasalahan tersebut. Penelitian ini dapat dijadikan pertimbangan sekolah dalam membuat program peningkatan prestasi belajar matematika.

\section{Kajian Literatur}

\section{Prestasi Belajar Matematika}

Prestasi belajar merupakan kombinasi antara kemampuan, usaha, keterampilan dan kejelasan tugas tanggung jawab (role perceptions). Prestasi belajar dipandang sebagai hubungan yang kompleks antara kemampuan individu, persepsi diri, penilaian terhadap tugas, harapan akan kesuksesan, strategi kognitif dan regulasi diri, gender, gaya pengasuhan, status sosio ekonomi, kinerja dan sikap individu terhadap sekolah (Clemons, 2008). Sungur dan Gungoren (2009), menemukan bahwa lingkungan sekolah mendorong siswa untuk meregulasi diri berpengaruh positif terhadap prestasi belajar.

Matematika merupakan ilmu universal yang mendasari perkembangan teknologi modern. Matematika mempunyai peran penting dalam berbagai disiplin ilmu dan memajukan daya pikir manusia. Perkembangan pesat di bidang teknologi informasi dan komunikasi dewasa ini tidak lepas dari hasil perkembangan matematika. Untuk menguasai dan mencipta teknologi di masa depan diperlukan penguasaan matematika yang kuat sejak dini. Pembelajaran matematika diharapkan dapat berperan dalam menyiapkan, meningkatkan dan membekali individu dan masyarakat di era yang penuh perubahan.

Matematika dapat meningkatkan kemampuan berpikir logis, analitis, sistematis, kritis, dan 
kreatif, serta kemampuan bekerjasama. Dengan demikian, pendidikan matematika mampu menyiapkan sumber daya manusia (SDM) yang berkualitas yang ditandai memiliki kemampuan memperoleh, mengelola, dan memanfaatkan informasi sesuai dengan tuntutan kebutuhan. Kompetensi tersebut diperlukan pada era persaingan global yang kompetitif. Pada era global ini akan terlihat jelas bahwa hanya bangsabangsa yang memiliki SDM berkualitas tinggi yang akan dapat survive, mencapai stabilitas nasional yang sehat dan dinamis, serta berkembang dan mencapai kemakmuran. Oleh karena itu mata pelajaran matematika perlu diajarkan kepada semua peserta didik mulai dari sekolah dasar.

Pendapat dan pandangan tentang pengertian matematika diatas dapat disimpulkan, antara lain: (1) matematika itu bahasa simbol; (2) matematika adalah bahasa numerik; (3) matematika adalah bahasa yang dapat menghilangkan sifat kabur, majemuk, dan emosional; (4) matematika adalah metode berpikir logis; (5) matematika adalah sarana berpikir; (6) matematika adalah logika pada masa dewasa; (7) matematika adalah ratunya ilmu dan sekaligus menjadi pelayannya; (8) matematika adalah ilmu pengetahuan mengenai kuantitas dan besaran, (9) matematika adalah ilmu pengetahuan yang bekerja menarik kesimpulankesimpulan yang perlu; (10) matematika adalah ilmu pengetahuan formal yang murni; (11) matematika adalah ilmu pengetahuan yang memanipulasi simbol; (12) matematika adalah ilmu tentang bilangan dan ruang; (13) matematika adalah ilmu yang mempelajari hubungan pola, bentuk, dan struktur; (14) matematika adalah ilmu yang abstrak dan deduktif; (15) matematika adalah aktivitas manusia.

\section{Self regulated learning}

Self regulated learning merupakan kesiapan dari individu yang mau dan mampu untuk belajar dengan inisiatif sendiri, dengan atau tanpa bantuan pihak lain dalam hal penentuan tujuan belajar, metode belajar, dan evaluasi prestasi belajar. Berkaitan dengan hal tersebut, Sugilar (2000) merangkum pendapat Guglielmino, West \& Bentley menyatakan bahwa karakteristik individu yang memiliki kesiapan belajar mandiri dicirikan oleh: (1) kecintaan terhadap belajar, (2) kepercayaan diri sebagai siswa, (3) keterbukaan terhadap tantangan belajar, (4) sifat ingin tahu, (5) pemahaman diri dalam hal belajar, dan (6) menerima tanggung jawab untuk kegiatan belajarnya.

\section{Self-efficacy}

Self-efficacy juga diperlukan dalam kegiatan belajar, antara lain keyakinan dalam diri seseorang mengenai kemampuannya untuk mengorganisir dan melakukan tindakan untuk mencapai tujuan yang telah ditentukan, dan juga dapat menampilkan perilaku yang dibutuhkan dalam mencapai tampilan atau hasil yang diinginkan dalam mencapai hasil yang diinginkan dari tuntutan tugas akademik yang di berikan. self-efficacy tersebut mempengaruhi persepsi, motivasi dan tindakannya dalam berbagai cara, termasuk dalam kemampuan akademiknya.

Seseorang yang memiliki self-efficacy yang tinggi akan membangun lebih banyak kemampuan-kemampuan melalui usaha- usaha mereka yang terus menerus, sedangkan selfefficacy yang rendah akan menghambat dan memperlambat perkembangan dari kemampuankemampuan yang di butuhkan seseorang.

Self-efficacy yang dipersepsikan tidak hanya sekedar perkiraan tentang tindakan apa yang akan dilakukan pada masa yang akan datang. Keyakinan seseorang mengenai kemampuan diri juga berfungsi sebagai suatu determinan bagaimana individu tersebut berperilaku, berpola pikir, dan bereaksi emosional terhadap situasisituasi yang sedang dialami. Keyakinan diri juga memberikan kontribusi terhadap kualitas dari fungsi psikososial seseorang.

\section{Perhatian Orangtua}

Keluarga adalah lingkungan masyarakat terkecil yang merupakan lingkungan pendidikan primer yang bersifat fundamental, sehingga sangat berperan dalam pembentukan proses pembelajaran anak. Besar kecilnya persoalan, sumbernya kembali pada pendidikan dan pertumbuhan sejak dini dalam keluarga, dimana perjalanan anak manusia secara bertahap dimulai sejak terbukanya mata terhadap kehidupan. Dalam hal seorang ibu mampu memainkan peranan sebagai secara utuh dan tepat, maka bukan saja dia telah memenuhi kewajibannya semata-mata melainkan telah ikut pula menabur 
andil bagi upaya memelihara kelangsungan hidup bangsa dan negara.

Orangtua pada pakekatnya mempunyai harapan agar anak-anaknya tumbuh dan berkembang menjadi anak yang baik agar tidak terjerumus kepada perbuatan-perbuatan yang dapat merugikan dirinya sendiri maupun orang lain. Harapan-harapan ini kiranya lebih mudah terwujud apabila sejak semula orangtua menyadari akan peranan mereka sebagai orangtua harus memperhatikan anak setiap hari walaupun sesibuk apapun, anak jangan sampai terlupakan dalam mengontrol dan mendidiknya, memberi kasih sayang dan memberi bimbingan.

Wilayah sekitar SMPN 1 Purwosari sebagian besar masyarakatnya bermatapencaharian sebagai petani dan bekerja di obyek wisata pantai parangtritis, mereka berangkat pagi dan pulang sore hari bahkan sampai malam hari, sehingga setelah pulang dari sawah/bekerja mereka lelah dan kurang memperhatikan perkembangan belajar anaknya. Didalam rumah anak-anak memerlukan perhatian dan kasih sayang dari orangtua. Pada dasarnya kurangnya perhatian orangtua dapat menyebabkan berbagai persoalan seperti malas belajar, bertingkah laku liar dan sulit berkonsentrasi dalam belajar, akibatnya prestasi belajar anak menurun.

Perhatian juga diberikan orangtua agar anaknya mendapatkan prestasi disekolahnya dan kelak dapat tercapai cita-citanya, selain itu agar anak mampu menjadi pribadi yang mandiri. Uraian latar belakang di atas mendorong peneliti untuk melakukan penelitian tentang bagaimana "Perngaruh self regulated learning, self-efficacy dan Perhatian orangtua Terhadap Prestasi Belajar Matematika Pada Siswa kelas VIII SMPN 1 Purwosari Gunungkidul tahun pelajaran 2014/2015?

\section{Metode Penelitian}

Penelitian ini menggunakan pendekatan kuantitatif. Dalam penelitian ini populasinya adalah seluruh siswa kelas VIII SMPN 1 Purwosari Gunungkidul, yang berjumlah tiga kelas dengan jumlah keseluruhan 89 siswa dengan rincian sebagaimana Tabel 1.
Tabel 1.

Tabulasi Jumlah Siswa Kelas VIII

\begin{tabular}{ccccc}
\hline No & Kelas & \multicolumn{3}{c}{ Jumlah Siswa } \\
& & L & P & $\sum$ \\
\hline 1 & VIII A & 13 & 16 & 29 \\
2 & VIII B & 17 & 13 & 30 \\
3 & VIII C & 15 & 15 & 30 \\
& Total & 45 & 44 & 89 \\
\hline
\end{tabular}

Instrumen pengumpulan data dalam penelitian ini adalah dengan menggunakan skala self regulated learning, skala self-efficacy, dan skala perhatian orangtua, yang disusun sendiri, dan untuk perolehan data tentang prestasi belajar diperoleh melalui data sekunder/dokumen.

Analisis data menggunakan perbandingan sekelompok yang berbeda, atau pengaruh antar variabel, serta melakukan interpretasi perbandingan antara hasil penelitian dengan yang diprediksikan sebelum penelitian Adapun pelaksanaan analisis data statistik menggunakan program Statistical Package for the Social Sciences (SPSS) 16.0 untuk melakukan analisis diskriptif, uji asumsi dan hipotesis.

Sementara itu uji hipotesis menggunakan metode analisis korelasi dan regresi linier berganda, di mana analisis ini digunakan untuk mengetahui pengaruh antara variabel independent dengan variabel dependent, apakah masingmasing variabel independent berpengaruh positif atau negatif

\section{Hasil Penelitian dan Pembahasan}

Hasil Analisis deskriptif dengan menggunakan SPSS 16.0 telah menunjukkan skor minimum, skor tertinggi, mean, dan standar deviasi dari masing-masing variabel. Tabel 2 merupakan hasil penghitungan analisis dengan SPSS 16.0. 
Tabel 2.

Hasil Analisis Deskriptif

\begin{tabular}{lccccc}
\hline \multicolumn{1}{c}{ Variabel } & N & Min. & Max. & Mean & $\begin{array}{l}\text { Standar } \\
\text { deviasi }\end{array}$ \\
\hline $\begin{array}{l}\text { Self } \\
\text { Regulated }\end{array}$ & 89 & 88 & 144 & 117,6404 & 11,33102 \\
Learning \\
$(X 1)$
\end{tabular}

\section{Deskripsi Self regulated learning}

Data self regulated learning pada tabel 2 diperoleh hasil dengan skor minimum sebesar 88 dan skor maximum diperoleh sebesar 144. Mean sebesar 117,6404 dan standar deviasi 11,33102.

\section{Deskripsi Self-efficacy}

Data self-efficacy pada tabel 2 diperoleh hasil dengan skor minimum sebesar 88 dan skor maximum diperoleh sebesar 177. Mean sebesar 135,5618 dan standar deviasi 12,81597

\section{Deskripsi Perhatian Orangtua}

Data perhatian orangtua pada tabel 2 diatas diperoleh hasil dengan skor minimum sebesar 76 dan skor maximum diperoleh sebesar 119. Mean sebesar 96,4831 dan standar deviasi 9,04925

\section{Pengujian Hipotesis}

\section{Analisis Regresi Linier Berganda}

Analisis regresi linier beganda digunakan untuk mengetahui pengaruh dua atau lebih variabel prediktor atau untuk mencari pengaruh fungsional dua variabel prediktor atau lebih terhadap variabel kriteriumnya, atau untuk meramalkan dua variabel prediktor atau lebih terhadap variabel kriteriumnya. Dengan demikian regresi ganda digunakan untuk penelitian yang menyertakan beberapa variabel sekaligus.
Penelitian ini dalam penghitungan regresi linier berganda menggunakan program SPSS 16.0, hasil analisis yang diperoleh setelah data diolah menggunakan program SPSS yang disajikan dalam Tabel 3.

Tabel 3.

Hasil Analisis Regresi Ganda

\begin{tabular}{lccc}
\hline \multicolumn{1}{c}{ Model } & $\begin{array}{c}\text { Under } \\
\text { standar } \\
\text { Dized } \\
\text { B }\end{array}$ & $\begin{array}{c}\text { Standar } \\
\text { dized }\end{array}$ & Sig. \\
& Beta & \\
\hline $\begin{array}{l}\text { (Constant) } \\
\text { Self Regulated }\end{array}$ & 72,691 & & 0,000 \\
$\begin{array}{l}\text { Learning (X1) } \\
\text { Self Efficacy } \\
\text { (X2) }\end{array}$ & 0,053 & 0,117 & 0,516 \\
$\begin{array}{l}\text { Perhatian } \\
\text { Orangtua (X3) }\end{array}$ & 0,035 & 0,087 & 0,611 \\
\hline
\end{tabular}

Pengambilan kesimpulan sebagai berikut:

a. Konstanta sebesar 72,691; artinya jika X1, X2, X3 nilainya adalah 0 , maka besarnya $\mathrm{Y}$ nilainya sebesar 72,691.

b. Koefisien regresi variabel $\mathrm{X}_{1}$ sebesar 0,053; artinya setiap peningkatan $\mathrm{X} 1$ sebesar 1 satuan, maka akan meningkatkkan Y sebesar 0,053 satuan, dengan asumsi variabel independen lain nilainya tetap.

c. Koefisien regresi variabel $\mathrm{X}_{2}$ sebesar 0,035; artinya setiap peningkatan $X_{2}$ sebesar 1 satuan, maka akan meningkatkan $\mathrm{Y}$ sebesar 0,035 satuan, dengan asumsi variabel independen lain nilainya tetap.

d. Koefisien regresi variabel $X_{3}$ sebesar -0,099; artinya setiap peningkatan $X_{3}$ sebesar 1 satuan, maka akan menurunkan $\mathrm{Y}$ sebesar 0,099 satuan, dengan asumsi variabel independen lain nilainya tetap.

\section{Hasil Analisis Determinasi (R Square)}

Analisis determinasi dalam regresi linear berganda digunakan untuk mengetahui prosentase sumbangan pengaruh variabel independen $\left(X_{1}\right.$, $\mathrm{X}_{2}, \mathrm{X}_{3}$ ) secara bersama-sama terhadap variabel dependen (Y). Koefisien ini menunjukkan seberapa besar prosentase variasi variabel independen yang digunakan dalam model mampu menjelaskan variasi variabel dependen. Hasil 
analisis determinasi dapat dilihat pada output model summary yang disajikan dalam Tabel 4.

Tabel 4

Hasil Analisis Determinasi (R Square) Model Summary

\begin{tabular}{lcrrr}
\hline Model & R & $\begin{array}{r}R \\
\text { Square }\end{array}$ & $\begin{array}{c}\text { Adjusted } \\
\text { Square }\end{array}$ & $\begin{array}{r}\text { Std.Error } \\
\text { of the } \\
\text { Estimate }\end{array}$ \\
\hline 1 & 0,166 & 0,028 & $-0,007$ & 5,142 \\
\hline
\end{tabular}

Dari hasil analisis pada Tabel 4 diperoleh nilai koefisien determinasi $\mathrm{R}$ ( $R$ Square) diperoleh angka sebesar 0,028 atau $(2,8 \%)$. Hal ini menunjukkan bahwa prosentase kontribusi pengaruh variabel independen self regulated learning (X1), self-efficacy (X2), dan perhatian orangtua (X3) terhadap variabel dependen prestasi belajar matematika (Y) sebesar 2,8\%. Self regulated learning, self-efficacy, dan perhatian orangtua hanya mampu menjelaskan sebesar 2,8\% terhadap prestasi belajar matematika. Sedangkan sisanya sebesar 97,2\% dijelaskan oleh variabel lain yang tidak diteliti.

Hasil analisis pada Tabel 5, dengan signifikansi 0,05 diperoleh hasil analisis signifikansi 0,494 atau lebih besar dari nilai signifikansi 0,05 (0,494 > 0,05), dengan demikian variabel independen self regulated learning, selfefficacy dan perhatian orangtua secara bersamasama tidak berpengaruh terhadap prestasi belajar matematika (Y).

Tabel. 5.

Hasil Analisis Varian

\begin{tabular}{lccccc}
\hline \multicolumn{1}{c}{ Model } & $\begin{array}{c}\text { Sum of } \\
\text { Squares }\end{array}$ & $d f$ & $\begin{array}{c}\text { Mean } \\
\text { Square }\end{array}$ & $F$ & Sig \\
\hline 1 & 63,931 & 3 & 21,310 & 5,142 & 0,494 \\
Regression & 2247,534 & 85 & 26,442 & & \\
Residual & 2311,465 & 88 & & & \\
\hline
\end{tabular}

Hasil pengujian hipotesis yang diajukan dalam penelitian ini menunjukkan ada pengaruh yang positif dan signifikan secara bersama-sama antara self regulated learning (X1), self-efficacy (X2) dan perhatian orangtua (X3) terhadap prestasi belajar matematika (Y). Secara bersama-sama variabel self regulated learning (X1), self-efficacy (X2), dan perhatian orangtua (X3), tidak berpengaruh terhadap prestasi belajar matematika (Y), Hal ini karena hasil analisis pada tabel 5 diatas, dengan signifikansi 0,05 diperoleh hasil signifikansi 0,494 atau lebih besar dari nilai signifikansi 0,05 $(0,494>0,05)$, dengan demikian maka Ha ditolak.

Terdapat pengaruh yang positif dan signifikan antara self regulated learning terhadap prestasi belajar matematika (Y). Hasil analisis pada tabel 3 dapat disimpulkan bahwa, variabel self regulated learning (X1) secara parsial tidak berpengaruh terhadap prestasi belajar matematika (Y), Hal ini karena hasil analisis nilai signifikansi self regulated learning didapatkan sebesar 0,516. Atau signifikansi lebih besar dari 5\% (0,516 > $0,05)$, dengan demikian maka Ha ditolak.

Terdapat pengaruh yang positif dan signifikan antara self-efficacy terhadap prestasi belajar matematika (Y). Hasil analisis pada tabel 3 dapat disimpulkan bahwa, variabel self-efficacy (X2) secara parsial tidak berpengaruh terhadap prestasi belajar matematika (Y), Hal ini karena dari hasil analisis nilai signifikansi didapatkan sebesar 0,611. atau taraf signifikansi lebih besar dari $5 \%$ $(0,611>0,05)$, dengan demikian maka Ha ditolak.

Terdapat pengaruh yang positif dan signifikan antara perhatian orangtua (X3) terhadap prestasi belajar matematika (Y). Hasil analisis pada tabel 3 dapat disimpulkan bahwa, variabel perhatian orangtua (X3) secara parsial tidak berpengaruh terhadap prestasi belajar matematika (Y), Hal ini karena nilai signifikansi yang didapatkan sebesar 0,193. atau signifikansi lebih besar dari 5\% $(0,193>0,05)$, dengan demikian maka Ha ditolak.

Hasil analisis pertama memperoleh hasil nilai signifikansi yang menunjukkan bahwa variabel self regulated learning (X1), self-efficacy (X2), dan perhatian orangtua (X3) secara bersama-sama tidak mempengaruhi prestasi belajar matematika (Y). Hipotesis pertama ditolak.

Hasil analisis penelitian ini membuktikan bahwa rendahnya prestasi belajar matematika siswa kelas VIII SMPN 1 Purwosari tidak dipengaruhi oleh self regulated learning, selfefficacy dan perhatian orangtua secara bersamasama, semakin tinggi self regulated learning, selfefficacy dan perhatian orangtua tidak mempengaruhi tinggi rendahnya prestasi belajar matematika siswa. Hasil penelitian membuktikan 
bahwa siswa kelas VIII SMPN 1 Purwosari mempunyai self regulated learning, self-efficacy dan perhatian orangtua pada tingkat sedang cenderung rendah, hal ini tidak mempengaruhi prestasi belajar matematika siswa dengan demikian prestasi belajar matematika dipengaruhi faktor lain yang tidak menjadi fokus dalam penelitian ini.

Penelitian Safitri (2003), membuktikan ada pengaruh yang signifikan antara Spiritual Quotient (SQ) terhadap prestasi belajar matematika, semakin tinggi tingkat SQ siswa, akan semakin tinggi pula prestasi belajar matematikanya.

Analisis parsial pertama memperoleh hasil variabel self regulated learning (X1) tidak berpengaruh secara signifikan terhadap variabel prestasi belajar matematika siswa. Hipotesis kedua ditolak. Prestasi belajar matematika yang diperoleh siswa, tidak dipengaruhi oleh bagaimana self regulated learning siswa itu sendiri. Hasil penelitian membuktikan bahwa siswa kelas VIII SMPN 1 Purwosari mempunyai self regulated learning pada tingkat sedang cenderung rendah, hal ini tidak mempengaruhi prestasi belajar matematika siswa dengan demikian rendahnya prestasi belajar matematika siswa kelas VIII ini dipengaruhi faktor lain yang tidak menjadi fokus dalam penelitian ini.

Menurut Schunk (2012), adakalanya siswa mengerjakan tugas pelajaran bukan karena mereka ingin belajar atau karena mereka menikmatinya, tetapi karena lebih disebabkan keinginan menghindari hukuman dan atau kritik dari guru. Menurut Prayitno (2009), kegagalankegagalan yang dialami siswa dalam belajar tidak selalu disebabkan oleh rendahnya intelegensi, tapi sering kegagalan itu terjadi disebabkan karena mereka tidak mendapatkan layanan bimbingan belajar yang memadai. Pendapat dari prayitno diatas sejalan dengan hasil penelitian bahwa rendahnya prestasi belajar matematika tidak dipengaruhi oleh self regulated learning siswa, hal ini dapat sebagai masukan pula bagi guru bimbingan konseling untuk lebih meningkatkan layanan bimbingan belajar kepada siswa.

Analisis parsial yang kedua memperoleh hasil variabel self-efficacy tidak berpengaruh secara signifikan terhadap variabel prestasi belajar matematika. Hipotesis ketiga ditolak. prestasi belajar matematika yang diperoleh siswa, tidak dipengaruhi oleh bagaimana self-efficacy siswa itu sendiri. Hasil penelitian membuktikan bahwa siswa kelas VIII SMPN 1 Purwosari mempunyai self-efficacy pada tingkat sedang cenderung rendah, hal ini tidak mempengaruhi prestasi belajar matematika siswa dengan demikian rendahnya prestasi belajar matematika siswa kelas VIII ini dipengaruhi faktor lain yang tidak menjadi fokus dalam penelitian ini. Menurut Schunk (2012), tidak selalu ada pengaruh antara efikasi diri dengan harapan-harapan akan hasil, bahkan siswa yang mempunyai efikasi diri yang tinggi untuk belajar, mungkin saja mengira bahwa mereka akan mendapatkan nilai yang rendah jika mereka berfikir bahwa gurunya tidak menyukai mereka, jadi peran dari guru dan metode pembelajaran guru juga dapat mempengaruhi prestasi belajar matematika siswa.

Menurut Schunk (2012), siswa mungkin saja meyakini bahwa sebuah sebuah hasil yang positif akan diperoleh dari tindakan-tindakan tertentu, teptapi mereka juga percaya bahwa mereka kurang memiliki kompetensi untuk melakukan tindakan-tindakan tersebut, sehingga hasilnya kurang maksimal sesuai dengan yang diharapkan.

Menurut Santrock (2008), self-efficacy instruksional dari guru berhubungan dengan prestasi akademik murid untuk pelajaran matematika dan bahasa, murid banyak belajar dari guru yang merasa yakin pada dirinya sendiri ketimbang guru yang ragu-ragu pada dirinya sendiri, guru yang keyakinan dirinya tinggi akan memandang murid bermasalah sebagai murid yang dapat diajar dan dijangkau dengan usaha lebih dan strategi yang baik untuk membantu murid.

Winkel (2012), melalui bekerja/belajar kelompok akan tercipta suasana belajar kooperatif, sehingga hasil yang diperoleh akan lebih baik daripada siswa belajar sendiri-sendiri, kualitas pemahaman akan lebih tinggi, kuantitas pengetahuan akan lebih banyak, sikap terhadap teman akan lebih terbuka, dan kelancaran dalam hubungan sosial akan lebih baik.

Menurut Santrock (2008), Sekolah dengan tingkat self-efficacy tinggi akan memiliki ekspektasi dan standar tinggi dalam hal prestasi. Guru menganggap murid sebagai anak didik yang mampu mencapai prestasi tinggi. Guru menentukan standar akademik yang menantang bagi murid, dan member bantuan kepada mereka 


\section{SUGIYANA}

untuk mencapai standar ini. Sedangkan sekolah dengan self-efficacy rendah tidak banyak berharap pada prestasi akademik murid, gurunya tidak banyak meluangkan waktu untuk mengajar dan memonitor kemajuan akademik murid, dan cenderung menganggap kebanyakan murid susah diajar, Brookover 1979 (Santrock, 2008). Menurut Hurlock (2008), kesuksesan akademik dan sosial anak lebih dipengaruhi oleh kualitas pengajaran yang diberikan kepada anak/siswa.

Hasil penelitian dari Ristiyandini (2012), membuktikan bahwa gaya kepemimpinan guru memberikan pengaruh yang positif dan signifikan terhadap prestasi belajar matematika, IPA, IPS dan PKn.

Analisis parsial yang ketiga memperoleh hasil variabel perhatian orangtua tidak berpengaruh terhadap variabel prestasi belajar matematika. Hipotesis keempat ditolak. Prestasi belajar matematika yang diperoleh siswa tidak banyak dipengaruhi oleh bagaimana perhatian orangtua terhadap siswa. Hasil penelitian membuktikan bahwa siswa kelas VIII SMPN 1 Purwosari mempunyai perhatian orangtua pada tingkat sedang cenderung rendah, hal ini tidak mempengaruhi prestasi belajar matematika siswa dengan demikian rendahnya prestasi belajar matematika siswa kelas VIII ini juga dipengaruhi faktor lain yang tidak menjadi fokus dalam penelitian ini. Menurut Crain (2007), Anak-anak yang tumbuh diwilayah-wilayah pedesaan yang miskin sering kali berkembang pada tingkatan yang rendah, tampaknya karena mereka tidak memiliki stimulasi intelektual, dengan kata lain lingkungan juga penting.

Hasil penelitian dari Kristiawan, Budiyono dan Purwoko dalam Jurnal Pendidikan (2013), hasil penelitian membuktikan bahwa, ada hubungan yang positif dan signifikan antara tingkat pendidikan formal orangtua terhadap prestasi belajar matematika siswa, semakin tinggi pendidikan formal orangtua maka semakin tinggi pula prestasi belajar matematikanya. Dari data pribadi siswa kelas VIII SMPN 1 Purwosari sangat sesuai dengan hasil penelitian diatas, bahwa sebagian besar orangtua siswa berpendidikan formal SMP ke bawah.

Menurut Hurlock (1998), Pada masa remaja awal/masa puber anak-anak cenderung berperilaku antisosial atau periode ketidakseimbangan/fase negatif, anak cenderung asik dengan dunianya sendiri dengan menjauh dan tidak memperdulikan orang lain disekitarnya termasuk orangtuanya. Hasil wawancara dengan beberapa orangtua siswa, memang benar sesuai dengan pendapat Hurlock diatas bahwa anak-anak pada saat ini lebih banyak menuruti kata temantemannya dari pada menuruti nasehat dari orangtuanya, keadaan ini yang sering membuat orangtua bingung harus mengambil langkah seperti apa dalam membimbing dan menasehati anaknya. Orangtua juga merasa minder dan tidak percaya diri untuk mendampingi anaknya dalam belajar dirumah, karena tingkat pendidikan formal orangtua yang relative sama dengan anaknya, bahkan dibawah anaknya sehingga merasa tidak mampu untuk membimbing anaknya dalam belajar dirumah. Menurut Santrock (2008), orangtua dengan pendidikan yang lebih tinggi akan lebih mungkin percaya bahwa keterlibatan mereka dalam pendidikan anak adalah penting, mereka lebih mungkin untuk berpartisipasi dalam pendidikan anak dan memberi stimuli intelektual dirumah, Schneider \& Coleman, 1993 (Santrock, 2008).

Orangtua kadang juga terlalu mempercayai anak, sering terjadi orangtua yang melacak anaknya apakah masih ada kegiatan disekolah saat sore hari, kadang siswa berpamitan untuk mengikuti kegiatan disekolah, hal ini membuktikan bahwa orangtua selalu mempercayai anak selama kegiatan yang berkaitan dengan belajar, tapi kepercayaan orangtua ini kadang disalah gunakan oleh anak untuk bermain dan melakukan kegiatan lain yang tidak berkaitan dengan belajar.

Menurut Hurlock (1978), masa puber/masa remaja awal, perubahan yang terjadi sangat mencolok dan jelas sehingga mengganggu keseimbangan yang sebelumnya telah terbentuk.Perilaku mereka mendadak menjadi sulit diduga dan seringkali agak melawan norma sosial yang berlaku. Pada masa ini orangtua merasakan anak sangat sulit diatur, dan anak cenderung menuruti kata teman-temannya dari pada menuruti nasehat orangtuanya, anak merasa sudah besar dan merasa dapat melakukan apapun secara sendiri, merasa apa yang dilihat diluar lebih baik untuk diikuti dan memberontak nasehat orangtua.

Menurut Schunk (2012), pengaruh dari teman akan meningkat selama masa kanak-kanak dan 
akan mencapai puncaknya pada saat anak kelas 8 dan kelas 9, setelah itu akan menurun pada saat anak masuk SMA. Dengan berdasar berbagai pendapat diatas maka penting dan perlu adanya koordinasi dan informasi tentang program sekolah yang harus diketahui oleh seluruh komponen sekolah dan juga orangtua siswa, demi kelancaran program sekolah dan juga demi kamajuan serta pendampingan anak dalam belajar baik disekolah maupun dirumah. Hubungan murid dengan orangtua, teman sebaya, kawan, guru, mentor dan orang lain di sekitarnya dapat mempengaruhi prestasi dan motivasi sosial mereka, (Santrock, 2008).

\section{Simpulan}

Hasil penelitian dapat disimimpulkan bahwa tidak ada pengaruh secara bersama-sama antara self regulated learning, self-efficacy, dan perhatian orangtua terhadap prestasi belajar matematika. Pengaturan diri yang baik, kepercayaan diri yang baik dan perhatian orangtua yang cukup, terbukti tidak mempengaruhi tinggi rendahnya prestasi belajar matematika siswa kelas VIII SMPN 1 Purwosari. Penelitian ini dapat dijadikan referensi bagi guru bimbingan konseling sebagai salah satu referensi dalam menyusun program layanan bimbingan kepada siswa.

\section{Referensi}

Alexander. (2006). Psychology in Learning and Instruction. Upper Saddle River.N.J: Merrill/Prentice Hall.

Arifin, (1991). Evaluasi Instruksional Prinsip Teknik Prosedur. Bandung: Remaja Rosdakarya.

Arikunto, S. (2002). Prosedur Penelitian: Suatu Pendekatan Praktek, Edisi Revisi V, Jakarta: PT Rineka Cipta.

Arikunto, S. (2010). Menejemen Penelitian. Jakarta : Rineka Cipta.

Azwar, S. (2012). Penyusunan Skala Psikologi, Yogyakarta: Pustaka Pelajar.

Bandura, A. (1997). Self-Efficacy: The Exercise of Control. New York: Freeman.

Crain, W, (2007). Teori Perkembangan Konsep dan Aplikasi Edisi Bahasa Indonesia. Yogyakarta: Pustaka Pelajar
Ghufron, M. N. \& Rini, S. R. (2010). Teori-Teori Psikologi. Yogyakarta: Ar-Ruzz Media

Hamalik, O. 2001. Kurikulum dan Pembelajaran. Jakarta: Bumi Aksara.

Hartono, 2014. SPSS Analisis Data Statistika dan Penelitian. Yogyakarta : Pustaka Pelajar

Hudojo, Herman. 1988. Mengajar Belajar Matematika. Jakarta: P2LPTK

Hurlock, E.B. 1978, Perkembangan Anak, terjemahan. Jakarta: Erlangga

Mc Cown, R. M. and Roop, P. G. 1997. Educational Psychology and Learning Approach to Classroom Practise. Boston; Allyn \& Bacon.

Prayitno, (2009). Dasar-dasar Bimbingan dan Konseling. Jakarta: Rineka Cipta

Priyatno, D. (2010). Paham Analisa Statistik Data Dengan SPSS. Yogyakarta: Media Kom

Russefendi, E.T. (2006). Pengajaran Matematika Modern. Bandung: Tarsito.

Santrock, J.W. (2008). Psikologi Pendidikan Terjemahan. Jakarta: Kencana Prenada Media Group

Santrock, J.W. (2011). Live-Span (Perkembangan Hidup) Terjemahan. Jakarta: Erlangga

Schunk, D.H. (2012). Learning Theories. Edisi keenam. Edisi Bahasa Indonesia. Penerjemah Eva Hamidah \& Rahmad Fajar. Yogyakarta: Pustaka Pelajar.

Slameto, (2010). Belajar dan Faktor-Faktor yang Mempengaruhinya, Jakarta: PT Rineka.

Sugiyono. (2008). Metode Penelitian Pendidikan (Pendekatan Kuantitatif, kualitatif, dan $R$ \& D). Bandung: Alfabeta

Sudjana, N. (2002). Penilaian hasil belajar. Bandung: PT. Rosda Karya.

Suparno, A. S. (2000). Membangun Kompetensi Belajar. Jakarta : Dikti Depdiknas

Suryabrata, S. (2011). Psikologi Pendidikan dan Kepribadian. Jakarta: PT. Raja Grafindo Persada.

Syah, M. (2003). Psikologi Pendidikan Dengan Pendekatan Baru. Bandung: Remaja Rosdakarya.

Syah, M. (2010). Psikologi Belajar. Jakarta: PT. Raja Grafindo Persada

Tafsir, A. (2008). Ilmu Pendidikan dan Perspektif Islam, Bandung: PT. Remaja Rosdakarya.

Ubaedy, A. (2007). Optimis Kunci Meraih Sukses. Jakarta: PT. Perspektif Media Komunika. 


\section{SUGIYANA}

Walgito, B. (2000). Psikologi Sosial Sebagai Pengantar. Yogyakarta: Andi Offset.

Widiyanto, M A. (2014). Statistika Terapan

Konsep \& Aplikasi SPSS/LISREL dalam
Penelitian Pendidikan, Psikologi \& Ilmu Sosial Lainnya. Jakarta: PT Gramedia.

Winkel, W.S. (2012). Psikologi Pengajaran. Yogyakarta: Media Abadi. 